\title{
UPAYA KEBERATAN DALAM PENGADAAN BARANG/JASA PEMERINTAH DIKAITKAN DENGAN PRINSIP DALAM GOVERNMENT PROCUREMENT AGREEMENT
}

\author{
Arief Budi Yulianto \\ email: ariefbudiyulianto@yahoo.com
}

\begin{abstract}
The Government Procurement Agreement (GPA), as part of agreements made within the purview of the World Trade Organization (WTO), opens up the doors for foreign businesses to enter the domestic market of government procurement (goods/services). Indonesia at present does not yet signed the GPA but decided to become an observer instead. Consequently, the government decides to harmonize its national laws regulating government procurement mechanism or procedure with the international standard (GPA). This article shows that there still exist a huge difference in how the national law regulates the public auction procedure (complaints, challenges and dispute resolution mechanism) with the GPA, which is used as a reference. This situation should be dealt with should Indonesia decides to sign and ratify the GPA.
\end{abstract}

Keywords: Government Procurement Agreement, challenge, right to challenge, complaint process.

\begin{abstract}
Abstrak
Government Procurement Agreement (GPA) sebagai bagian dari kesepakatan yang dibuat di bawah World Trade Organization (WTO), bertujuan membuka kesempatan bagi pelaku usaha dari negara lain untuk berpartisipasi dalam pengadaan barang/jasa pemerintah di Indonesia. Indonesia sampai saat ini masih menjadi observer dan belum menjadi anggota GPA, namun pada saat sama telah mulai mengikuti atau menyesuaikan hal-hal yang ada dalam GPA, antara lain, aturan mengenai prosedur keberatan dan banding. Tulisan ini akan membahas dan membandingkan prosedur keberatan dan banding dalam Peraturan Presiden Nomor 54 Tahun 2010 tentang Pengadaan Barang/Jasa Pemerintah dengan aturan-aturan serupa dalam GPA. Penelitian menunjukkan masih adanya perbedaan prosedur pengaturan keberatan, sanggahan maupun pengaduan antara kedua aturan tersebut. Hal ini harus diperhatikan bilamana suatu saat nanti Indonesia memutuskan menandatangani GPA.
\end{abstract}

Kata kunci: Kesepakatan Kerjasama Pemerintah, keberatan, sanggahan, pengaduan.

\section{Pendahuluan}

Persetujuan umum mengenai Tarif dan Perdagangan General Agreement on Tariffs and Trade - GATT mengatur kebijakan perdagangan antar negara dibentuk pada tahun 1947. Lahirnya World Trade Organization (WTO) pada tahun 1994 merupakan perubahan yang sangat penting bagi GATT, WTO mengambil alih GATT dan menjadikannya salah satu lampiran aturan WTO. Prinsip-prinsip GATT menjadi kerangka aturan bagi bidang-bidang baru dalam perjanjian WTO, 
khususnya Perjanjian mengenai Jasa General Agreement on Trade in Services (GATS), Penanaman Modal Trade-Related Investment Measures (TRIMs) dan juga mengenai Perjanjian mengenai perdagangan yang terkait dengan Hak Atas Kekayaan Intelektual Trade-Related Aspects of Intellectual Property Rights (TRIPs).

General Agreement on Trade in Services yang selanjutnya disebut dengan GATS merupakan perjanjian perdagangan multilateral yang pertama di bidang jasa. GATS merupakan salah satu perjanjian di bawah World Trade Organization (WTO). GATS merupakan hasil dari Uruguay Rounds mulai berlaku sejak 1 Januari 1995. Negara anggota GATS diwajibkan untuk membuka sektor-sektor jasa untuk diliberalisasi dengan menyusun jadwal, bagaimana, apa seberapa dalam dan seberapa luas sektor tersebut dibuka untuk pemasok jasa asing. Dibentuknya GATS adalah untuk membentuk suatu kerangka prinsip-prinsip atau aturanaturan material dalam perdagangan jasa. Prinsip-prinsip dalam GATS harus dilaksanakan oleh negara anggota antara lain yaitu prinsip Most Favoured Nation, prinsip National Treatment, prinsip transparansi.

Dalam setiap pertemuan dalam forum WTO, Asia Pacific Economic Coperation (APEC) dan Asian European Meeting (ASEM), Indonesia selalu dihadapkan kepada permintaan untuk melakukan ratifikasi terhadap Government Procurement Agreement (GPA). Pada dasarnya ratifikasi terhadap GPA adalah pembukaan pasar Indonesia (market access) kepada pengusaha-pengusaha dari negara lain, yang berarti mengizinkan perusahaan asing dapat ikut serta pada proses pengadaan barang/jasa pemerintah Indonesia, baik di pusat maupun di daerah. Pada umumnya GPA tersebut memiliki threshold yang cukup rendah, yaitu sekitar US\$ 35,000 (tigapuluh lima ribu) untuk pengadaan supplies (alat-alat tulis, alat keperluan kantor, pembelian barang-barang lain). Sedangkan untuk construction, threshold-nya sekitar US\$ 5.000.000 (lima juta). Artinya apabila kita sudah meratifikasi GPA, maka untuk pengadaan di atas threshold tersebut harus kita lakukan dengan International Competitive Bidding (ICB), yang berarti 
perusahaan asing boleh ikut menjadi peserta dan tidak boleh ada perlakuan diskriminatif terhadap perusahaan asing tersebut. ${ }^{1}$

Bahwa hambatan bagi perusahaan-perusahaan multinasional untuk ikut terlibat dalam pengadaan barang dan jasa ini, bahwa sektor Government Procurement merupakan sektor yang dikecualikan dalam ruang lingkup pengaturan tentang perdagangan yang diatur oleh WTO baik mengenai barang dan jasa, dalam persetujuan tentang Tarif dan Perdagangan (General Agreement on Tariffs and Trade - GATT) tahun 1947, Government Procurement dikeluarkan dari kewajiban National Treatment atau non diskriminasi. Hal tersebut juga berlaku terhadap ketentuan Persetujuan Umum tentang Perdagangan Jasa (General Agreement on Trade Services - GATS). Sudah lama negara maju melakukan upaya agar Government Procurement menjadi bagian dari GATT, pada tahun 1976 disetujui ada suatu grup mengenai Government Procurement. Selanjutnya pada Tokyo Round disetujui adanya Government Procurement Agreement (GPA).

Dalam GPA terdapat ketentuan agar Undang-Undang, peraturan, prosedur, dan praktek-praktek tentang pengadaan barang kebutuhan pemerintah menjadi lebih terbuka (transparan) dan menjamin bahwa prosedur tersebut tidak melindungi produk atau penyedia barang/jasa dalam negeri. GPA juga membuat ketentuan bagi perlakuan khusus dan perlakuan yang tidak sama bagi negaranegara berkembang serta negara miskin, termasuk keperluan-keperluan khusus mereka dalam pembangunan, keuangan dan perdagangan. ${ }^{2}$ Anggota GPA terdiri dari 19 negara dari 47 negara anggota WTO. Hingga saat ini Indonesia walaupun merupakan anggota WTO namun belum ikut serta dalam GPA, oleh karena itu posisi Indonesia dalam GPA adalah sebagai observer bersama 28 negara anggota WTO lainnya. ${ }^{3}$

1 Kwik Kian Gie, Kebijakan Pengadaan Barang/Jasa Instansi Pemerintah (Government's Goods/Services Procurement), Naskah pidato Menteri Negara Perencanaan Pembangunan Nasional/Kepala Bappenas pada Pertemuan Tingkat Menteri di Jakarta, dalam Konferensi Tingkat Menteri (KTM) WTO-V di Cancun Mexico, 7 Agustus 2003, hlm., 3.

2 H.S. Kartajoemena, GATT, WTO dan Hasil Uruguay Round, Universitas Indonesia, Jakarta, 2002, hlm., 214.

3 Agreement on Government Procurement Parties, Observers and Accessions diakses dari https://www.wto.org/english/tratop_e/gproc_e/memobs_e.html pada tanggal 13 Oktober 2016. 
Walaupun Indonesia belum menjadi anggota atau meratifikasi GPA namun secara perlahan Indonesia menyesuaikan dengan dasar-dasar dalam GPA. Hal tersebut dalam rangka mempersiapkan untuk bergabung menjadi anggota GPA. Beberapa hal yang menjadi penyesuaian antara lain dalam hal pengadaan barang/jasa Pemerintah, sudah ada beberapa prinsip-prinsip yang diterapkan atau disesuaikan dengan GPA. Prinsip efisien, efektif, transparan, terbuka, bersaing, adil/tidak diskriminatif dan akuntabel adalah prinsip dalam pengadaan barang/jasa Pemerintah.

Pengadaan barang/jasa merupakan upaya untuk mendapatkan barang/jasa yang diinginkan dengan menggunakan metode dan proses tertentu agar dicapai kesepakatan harga, waktu dan kesepakatan lainnya. Agar pengadaan barang/jasa dapat dilaksanakan dengan baik maka kedua belah pihak yaitu pengguna dan penyedia harus selalu mengikuti prinsip-prinsip, metode dan proses pengadaan barang dan jasa yang berlaku.

Sistem pengadaan barang/jasa yang baik adalah sistem pengadaan yang mampu menerapkan prinsip-prinsip tata pemerintahan yang baik (good governance), mendorong efisiensi dan efektivitas pengeluaran anggaran dalam penyelenggaaan tata pemerintahan yang baik. Saat ini pemerintah berusaha untuk mewujudkan pemerintahan yang terbuka dan demokratis dengan meningkatkan dan mengoptimalkan pelayanan publik terhadap masyarakat melalui kebijakan atan peraturan yang efektif, efisien dan mencerminkan keterbukaan. Pelaksanaan pengadaan barang/jasa Pemerintah yang saat ini masih berlaku diatur dalam Peraturan Presiden tentang Pengadaan Barang/Jasa Pemerintah mulai tahun 2010 sebagaimana telah beberapa kali diubah.

Secara historis pengaturan pelaksanaan pengadaan barang dan jasa oleh Pemerintah sejak tahun 2010 sudah terdapat beberapa kali perubahan. Perubahan-perubahan peraturan tersebut adalah agar pelaksanaan pengadaan barang/jasa Pemerintah lebih baik dan untuk mengurangi penyimpangan yang dapat merugikan keuangan negara. Saat ini proses pelaksanaan peraturan tersebut sebagaimana diatur dalam Peraturan Presiden Nomor 54 Tahun 2010 sebagaimana telah beberapa kali diubah, terakhir dengan Peraturan Presiden 
Nomor 4 Tahun 2015 telah menggunakan sistem e-procurement. E-procurement adalah proses pengadaan barang dan jasa secara on line melalui internet, dimana seluruh proses pengumuman, pendaftaran, proses penawaran, aanwijzing, hasil evaluasi atas penawaran dilakukan dengan memanfaatkan sarana teknologi informasi. ${ }^{4}$

E-procurement memiliki fungsi utama untuk menjamin proses pengadaan barang/jasa Pemerintah sesuai dengan ketentuan yang berlaku. Selain itu, $e$ procurement juga menjamin terciptanya transparansi, standarisasi, dan akuntabilitas proses pengadaan yang dapat diikuti dan diawasi secara bersamasama oleh masyarakat. Proses yang transparan dalam pengadaan barang/jasa akan memberikan kesempatan yang sama kepada penyedia barang/jasa dan dalam pelaksanaannya akan mendapatkan pengawasan dari masyarakat. Yang terpenting adalah bahwa, e-procurement secara khusus atau pengadaan barang/jasa Pemerintah secara umum, harus berpihak pada peningkatan kualitas pelayanan publik, tata kelola pemerintahan yang baik, dan kesejahteraan rakyat yang digadang-gadang dalam konsep good governance. ${ }^{5}$

Sanggahan setelah adanya pengumuman pemenang dapat diajukan peserta pengadaan barang/jasa yang merasa dirugikan apabila menemukan penyimpangan, adanya rekayasa dan penyalahgunaan wewenang terhadap ketentuan prosedur yang telah ditetapkan dalam dokumen pengadaan barang/jasa yang dapat mengakibatkan terjadinya persaingan yang tidak sehat. Dalam Peraturan Presiden Pengadaan Barang/Jasa Pemerintah juga mengatur mengenai pengaduan yang cakupannya lebih luas yaitu tidak hanya peserta pengadaan saja yang dapat mengajukan pengaduan, masyarakat yang menemukan indikasi-indikasi penyimpangan tersebut juga dapat mengajukan pengaduan.

Pengaduan dapat dilakukan dalam hal Penyedia Barang/Jasa atau masyarakat menemukan indikasi penyimpangan prosedur, KKN dalam

\footnotetext{
${ }^{4}$ Mochammad Jasin, Mencegah Korupsi Melalui E-procurement, Komisi Pemberantasan Korupsi, Jakarta, 2007, hlm,. 3.

5 Samsul Ramli, Bacaan Wajib Para Praktisi Pengadaan Barang/Jasa Pemerintah, Visimedia, Jakarta, 2013, hlm., 11.
} 
pelaksanaan pengadaan barang/jasa Pemerintah dan atau pelanggaran persaingan yang sehat dapat mengajukan pengaduan proses pemilihan Penyedia Barang/Jasa. Sedangkan di dalam GPA diatur mengenai Challenge Procedures apabila adanya upaya keberatan dalam proses pengadaan. Upaya keberatan dikaitkan dengan Government Procurement Agreement (GPA) yang merupakan salah satu perjanjian di dalam World Trade Organization (WTO) memiliki prinsipprinsip di GPA yaitu adanya ketepatan waktu, efektif, transparan dan tidak diskriminatif dalam pengadaan barang/jasa.

Metode yang digunakan pada penulisan ini menggunakan metode kualitatif, yaitu menganalisa asas-asas dalam peraturan perundang-undangan. Penelitian Yuridis Normatif di sini dimaksudkan bahwa permasalahan yang menjadi obyek kajian dianalisis berdasarkan pada sumber-sumber berupa peraturan-peraturan, perundang-undangan yang berlaku, teori-teori hukum dan pendapat-pendapat para sarjana hukum terkemuka.

Metode penelitian dengan pendekatan yuridis normatif yang ditujukan untuk memahami penerapan norma-norma hukum terhadap fakta yang menitikberatkan fokus kajian pada asas-asas dan kaidah-kaidah hukum yang terdapat di berbagai ketentuan perundang-undangan yang berlaku maupun teoriteori hukum dalam berbagai literatur. ${ }^{6}$

Selain itu metode komparatif untuk membandingkan satu hal dengan hal lainnya. Untuk membandingkan persamaan dan perbedaan dua atau lebih faktafakta dan sifat-sifat objek yang di teliti berdasarkan kerangka pemikiran tertentu.

\section{Pembahasan}

\section{Sejarah Dan Prinsip GPA}

General Agreement on Tariffs and Trade (GATT) berpedoman pada 5 prinsip utama yaitu prinsip Most-Favoured Nation, National Treatment, Larangan Restriksi (Pembatasan) Kuantitatif, perlindungan melalui tarif, resiprositas, perlakuan khusus bagi negara sedang berkembang. Prinsip Most-Favoured Nation

\footnotetext{
${ }^{6}$ Soerjono Soekanto dan Sri Mamudji, Penelitian Hukum Normatif: Suatu Tinjauan Singkat, Rajawali Pers, Jakarta, 2012, hlm., 11.
} 
menyatakan bahwa suatu kebijakan perdagangan harus dilaksanakan atas dasar non-diskriminatif. Menurut prinsip ini, semua negara anggota terikat untuk memberikan negara-negara lainnya perlakuan yang sama dalam pelaksanaan dan kebijakan impor dan ekspor serta yang menyangkut biaya-biaya lainnya. Menurut prinsip National Treatment, produk dari suatu negara yang diimpor ke dalam suatu negara harus diperlakukan sama seperti halnya produk dalam negeri. Restriksi kuantitatif terhadap ekspor atau impor juga diatur dalam GATT, dalam pelaksanaannya pembatasan ini dikecualikan pada negara-negara sedang berkembang. Dalam hal ini negara tersebut dapat memberlakukan restriksi kuantitatif untuk mencegah terkurasnya valuta asing (devisa) mereka yang disebabkan oleh adanya permintaan untuk impor dan juga diperlukan untuk memperluas produksi dalam negeri negara berkembang. Sedangkan perlakuan khusus bagi negara sedang berkembang, yaitu negara-negara anggota sepakat dan mengeluarkan putusan mengenai pemberian perlakuan yang lebih menguntungkan dan partisipasi yang lebih besar bagi negara sedang berkembang dalam perdagangan dunia. Pengakuan ini juga merupakan dasar hukum bagi negara industri untuk memberikan GSP (Generalized System of Preferences atau sistem preferensi umum) kepada negara-negara sedang berkembang.

Prinsip pembentukan dan dasar WTO adalah untuk mengupayakan keterbukaan batas wilayah, memberikan jaminan atas Most Favoured Nation dan perlakuan non diskriminasi dalam negara-negara anggota serta komitmen terhadap transparansi. Terbukanya pasar nasional terhadap perdagangan internasional diharapkan akan mendorong dan membantu pembangunan yang berkesinambungan, meningkatkan kesejahteraan, mengurangi kemiskinan, dan membangun perdamaian dan stabilitas.

GPA merupakan perjanjian multilateral dalam kerangka WTO, yaitu perjanjian di bidang government procurement hanya mengikat negara yang turut dalam perjanjian ini namun tidak semua anggota WTO merupakan pihak dalam GPA. Selama suatu negara belum menandatangani atau ikut dalam GPA, maka GPA tersebut tidak berlaku bagi negara itu. Saat ini anggota GPA berjumlah 19 negara dari 47 negara anggota WTO. Anggotanya adalah Armenia, Kanada, Uni Eropa, 
Hongkong, Islandia, Israel, Jepang, Korea Selatan, Liechtenstein, Moldova, Montenegro, Belanda Aruba, Selandia Baru, Norwegia, Singapura, Swiss, China Taipei, Ukraina, Amerika Serikat. Sedangkan observer-nya adalah Albania, Argentina, Australia, Bahrain, Kamerun, Chili, Kolombia, Kosta Rika, Georgia, India, Indonesia, Yordania, Kazakhstan, Republik Kirgizstan, Malaysia, Mongolia, Oman, Panama, Pakistan, Federasi Rusia, Arab Saudi, Seychelles, Sri Lanka, Tajikistam, Thailand, Republik Makedonia, Turki, Vietnam, dimana saat ini 8 negara observer sedang melakukan negosiasi untuk menjadi anggota GPA.

Indonesia sebagai observer belum menjadi anggota. GPA mempunyai tujuan untuk memastikan keterbukaan, adil, dan transparan dalam persaingan pengadaan pemerintah untuk negara-negara anggota GPA. Dalam GPA ditetapkan aturan keterbukaan, adil, dan transparan kepada negara-negara anggota, namun tidak secara otomatis berlaku keterbukaan untuk pengadaan oleh Pemerintah masing-masing negara anggota. Ada jadwal yang merupakan hal penting dalam menentukan kegiatan pengadaan oleh Pemerintah mana yang bisa dibuka atau tertutup bagi para negara anggota GPA.

Alasan-alasan terbentuknya GPA terdapat dalam bagian awal Legal Text Agreement on Government Procurement yaitu:

1. Bahwa diperlukannya suatu bentuk pengaturan dalam bidang Government Procurement untuk perdagangan internasional yang efektif.

2. Bahwa ketentuan mengenai Government Procurement bukan untuk memberikan perlindungan terhadap barang atau jasa domestik saja dan seharusnya tidak menyebabkan diskriminasi terhadap barang dan jasa asing dan pihak penyedia barang dan jasa asing.

3. Bahwa diperlukannya suatu peraturan mengenai Governent Procurement yang bersifat transparan.

Indonesia sebagai observer memperoleh akses langsung terhadap informasi mengenai perkembangan proses penyempurnaan standar internasional atas sistem pengadaan Pemerintah yang transparan, akuntabel dan non-diskriminatif. Dalam perkembangannya, Indonesia mulai menyesuaikan standar internasional 
dalam GPA ke dalam pengadaan barang jasa Pemerintah yaitu dengan adanya peraturan-peraturan pengadaan barang/jasa yang selalu berkembang.

Prinsip-prinsip GPA harus dilaksanakan oleh negara anggota antara lain, prinsip Most Favoured Nation dikenal juga sebagai prinsip non diskriminasi, prinsip National Treatment, yaitu setiap negara anggota memperlakukan jasa-jasa dan pemberi jasa dari negara anggota lainnya harus sama dengan perlakukan yang diberikan terhadap jasa atau pemberi jasa dari negaranya, prinsip selanjutnya adalah prinsip transparansi pada intinya negara anggota harus mempublikasikan regulasi atau kebijakan yang terkait dengan perdagangan jasa.

\section{Pengadaan Barang/Jasa Pemerintah}

Anggaran Pendapatan Belanja Negara (APBN) dan Anggaran Pendapatan Belanja Daerah (APBD) Indonesia sangat besar sehingga menarik pelaku usaha asing untuk terlibat dalam penyediaan barang/jasa Pemerintah. Berdasarkan beberapa kondisi, Pemerintah Indonesia hingga saat ini belum memutuskan untuk menjadi anggota dan meratifikasi GPA. Sedangkan pelaku usaha asing terus berusaha untuk masuk dan mempengaruhi dalam proses pengadaannya, karena perkembangan yang sangat cepat, kebutuhan akan pengadaan sangat tinggi.

Pengadaan barang/jasa Pemerintah di Indonesia saat ini berdasarkan Peraturan Presiden Republik Indonesia Nomor 4 Tahun 2015 tentang Perubahan Keempat Atas Peraturan Presiden Republik Indonesia Nomor 54 Tahun 2010 tentang Pengadaan Barang/Jasa Pemerintah. Prinsip-prinsip yang ada di dalamnya adalah sebagai berikut:

a. Efisien, berarti Pengadaan Barang/Jasa harus diusahakan dengan menggunakan dana dan daya yang minimum untuk mencapai kualitas dan sasaran dalam waktu yang ditetapkan atau menggunakan dana yang telah ditetapkan untuk mencapai hasil dan sasaran dengan kualitas yang maksimum.

b. Efektif, berarti Pengadaan Barang/Jasa harus sesuai dengan kebutuhan dan sasaran yang telah ditetapkan serta memberikan manfaat yang sebesarbesarnya. 
c. Transparan, berarti semua ketentuan dan informasi mengenai Pengadaan Barang/Jasa bersifat jelas dan dapat diketahui secara luas oleh Penyedia Barang/Jasa yang berminat serta oleh masyarakat pada umumnya.

d. Terbuka, berarti Pengadaan Barang/Jasa dapat diikuti oleh semua Penyedia Barang/Jasa yang memenuhi persyaratan/kriteria tertentu berdasarkan ketentuan dan prosedur yang jelas.

e. Bersaing, berarti Pengadaan Barang/Jasa harus dilakukan melalui persaingan yang sehat di antara sebanyak mungkin Penyedia Barang/Jasa yang setara dan memenuhi persyaratan, sehingga dapat diperoleh Barang/Jasa yang ditawarkan secara kompetitif dan tidak ada intervensi yang mengganggu terciptanya mekanisme pasar dalam Pengadaan Barang/Jasa.

f. Adil/tidak diskriminatif, berarti memberikan perlakuan yang sama bagi semua calon Penyedia Barang/Jasa dan tidak mengarah untuk memberi keuntungan kepada pihak tertentu, dengan tetap memperhatikan kepentingan nasional.

g. Akuntabel, berarti harus sesuai dengan aturan dan ketentuan yang terkait dengan Pengadaan Barang/Jasa sehingga dapat dipertanggungjawabkan.

Berdasarkan Pasal 57, ayat (1) huruf d, tahapan pemilihan penyedia barang/pekerjaan konstruksi/jasa lainnya dengan metode pelelangan umum dengan pascakualifikasi yang meliputi kegiatan:

1) pengumuman;

2) pendaftaran dan pengambilan Dokumen Pengadaan;

3) pemberian penjelasan;

4) pemasukan Dokumen Penawaran;

5) pembukaan Dokumen Penawaran;

6) evaluasi penawaran;

7) evaluasi kualifikasi;

8) pembuktian kualifikasi;

9) pembuatan Berita Acara Hasil Pelelangan;

10) penetapan pemenang;

11) pengumuman pemenang;

12) sanggahan; dan 
13) penunjukan Penyedia Barang/Jasa.

Bahwa setelah adanya pengumuman pemenang ada proses untuk upaya keberatan terhadap proses-proses pengadaan barang/jasa Pemerintah sehingga diperlukan adanya keputusan terhadap keberatan yang diajukan dengan berdasarkan prosedur yang tidak diskriminasi, tepat waktu, efektif dan transparan. Sanggahan setelah adanya pengumuman pemenang peserta pengadaan barang/jasa yang merasa dirugikan apabila menemukan penyimpangan terhadap ketentuan dan prosedur yang diatur dalam Peraturan Presiden dan yang telah ditetapkan dalam dokumen pengadaan barang/jasa, adanya rekayasa yang mengakibatkan terjadinya persaingan yang tidak sehat, dan/atau adanya penyalahgunaan wewenang oleh ULP dan/atau pejabat yang berwenang lainnya.

Surat sanggahan disampaikan kepada kelompok Kerja ULP dan ditembuskan kepada PPK, PA/KPA dan APIP K/L/D/I yang bersangkutan paling lambat 3 (tiga) hari kerja untuk Pelelangan/Seleksi Sederhana dan Pemilihan Langsung. Sedangkan untuk Pelelangan/Seleksi Umum paling lambat 5 (lima) hari kerja setelah pengumuman pemenang. Selanjutnya ULP wajib memberikan jawaban tertulis atas semua sanggahan paling lambat paling lambat 3 (tiga) hari kerja untuk Pelelangan/Seleksi Sederhana dan Pemilihan Langsung. Sedangkan untuk Pelelangan/Seleksi Umum paling lambat 5 (lima) hari kerja hari kerja setelah surat sanggahan diterima.

Dahulu sebelum Peraturan Presiden Nomor 4 Tahun 2015 terdapat proses sanggah banding, yaitu keberatan terhadap jawaban sanggah yang diajukan kepada kepada Menteri/Pimpinan Lembaga/Kepala Daerah/Pimpinan Institusi paling lambat dalam jangka waktu paling lambat 3 (tiga) hari kerja untuk Pelelangan/Seleksi Sederhana dan Pemilihan Langsung. Sedangkan untuk Pelelangan/Seleksi Umum paling lambat 5 (lima) hari kerja hari kerja setelah diterimanya jawaban sanggah, dengan adanya Peraturan Presiden Nomor 4 Tahun 2015 proses sanggah banding ditiadakan. 


\section{Challenge Procedure}

Artikel XX GPA mengatur mengenai prosedur challenge dalam hal terjadi keberatan dari peserta lelang dalam proses pengadaan, yaitu masing-masing negara anggota harus mencari resolusi keberatan dalam konsultasi dengan suatu badan yang berkaitan dengan panitia pengadaan. Apabila terdapat permasalahan, badan pengadaan memberikan pertimbangan yang tidak memihak dan tepat waktu untuk setiap keluhan tersebut, dengan prosedur yang tidak merugikan memperoleh langkah-langkah perbaikan dalam proses pengadaan tersebut.

\section{Article XX}

Challenge Procedures

\section{Consultations}

1. In the event of a complaint by a supplier that there has been a breach of this Agreement in the context of a procurement, each Party shall encourage the supplier to seek resolution of its complaint in consultation with the procuring entity. In such instances the procuring entity shall accord impartial and timely consideration to any such complaint, in a manner that is not prejudicial to obtaining corrective measures under the challenge system.

Challenge

2. Each Party shall provide non-discriminatory, timely, transparent and effective procedures enabling suppliers to challenge alleged breaches of the Agreement arising in the context of procurements in which they have, or have had, an interest.

3. Each Party shall provide its challenge procedures in writing and make them generally available.

4. Each Party shall ensure that documentation relating to all aspects of the process concerning procurements covered by this Agreement shall be retained for three years.

5. The interested supplier may be required to initiate a challenge procedure and notify the procuring entity within specified time-limits from the time when the basis of the complaint is known or reasonably should have been known, but in no case within a period of less than 10 days.

6. Challenges shall be heard by a court or by an impartial and independent review body with no interest in the outcome of the procurement and the members of which are secure from external influence during the term of appointment. A review body which is not a court shall either be subject to judicial review or shall have procedures which provide that:

(a) participants can be heard before an opinion is given or a decision isreached;

(b) participants can be represented andaccompanied; 
(c) participants shall have access to all proceedings;

(d) proceedings can take place in public;

(e) opinions or decisions are given in writing with a statement describing the basis for the opinions or decisions;

(f) witnesses can be presented;

(g) documents are disclosed to the review body.

7. Challenge procedures shall provide for:

(a) rapid interim measures to correct breaches of the Agreement and to preserve commercial opportunities. Such action may result in suspension of the procurement process. However, procedures may provide that overriding adverse consequences for the interests concerned, including the public interest, may be taken into account in deciding whether such measures should be applied. In such circumstances, just cause for not acting shall be provided in writing;

(b) an assessment and a possibility for a decision on the justification of the challenge;

(c) correction of the breach of the Agreement or compensation for the loss or damages suffered, which may be limited to costs for tender preparation or protest.

8. With a view to the preservation of the commercial and other interests involved, the challenge procedure shall normally be completed in a timely fashion.

Dalam Artikel XX GPA tersebut dijelaskan bahwa anggota-anggota GPA harus menyediakan prosedur keberatan tersebut secara tertulis, disertai dokumen-dokumen pendukung yang berkaitan dengan proses pengadaan barang/jasa yang mempunyai pengaturan jangka waktu penyelesaiannya. Prosedur challenges dalam GPA dapat berupa pengadilan atau suatu badan imparsial dan independen yang tidak mempunyai kepentingan di dalam pengadaan barang/jasa yang aman dari pengaruh eksternal. Apabila badan tersebut bukan pengadilan paling tidak badan tersebut mempunyai persyaratanpersyaratan dalam menyelenggarakan prosedur penanganannya.

Bahwa apabila badan peninjau atau badan pelaksana terhadap upaya keberatan berdasarkan GPA tersebut bukanlah pengadilan, paling tidak mempunyai prosedur, antara lain peserta dapat didengar pendapatnya terlebih dahulu sebelum keputusan diambil, adanya keadaan peserta dapat diwakili dan ikut, peserta memiliki akses ke dalam proses, proses berlangsung terbuka secara 
umum, pendapat atau keputusan diberikan secara tertulis dengan menjelaskan pertimbangan-pertimbangan terhadap putusan yang diambil, adanya kesempatan saksi untuk dihadirkan, dan dokumen yang tidak tertutup terhadap badan peninjau tersebut.

Proses penyampaian keberatan di dalam GPA bertujuan untuk menerapkan langkah-langkah yang cepat untuk memperbaiki pelanggaran dalam proses pengadaan barang/jasa yang dimungkinkan hasilnya adalah penangguhan atau pembatalan proses pengadaan. Apabila pembatalan proses pengadaan berpengaruh besar terhadap kepentingan umum, maka pertimbangan dalam pemberian putusan harus mempertimbangkan apakah penangguhan atau pembatalan proses pengadaan dapat diterapkan. Putusan-putusan seperti itu harus dilakukan secara tertulis. Selain itu bertujuan untuk memberikan penilaian terhadap keluhan atau keberatan, dan koreksi terhadap adanya perjanjian atau proses dalam pengadaan yang terbatas pada persiapan dan kerugian yang diderita oleh peserta pemilihan barang/jasa.

\section{Upaya Keberatan}

Apabila hal tersebut di atas dikaitkan dengan upaya keberatan dalam Pengadaan Barang/Jasa Pemerintah di Indonesia, sudah ada pengaturan di dalamnya mengenai proses upaya keberatan, yaitu seperti dijelaskan adanya proses sanggah dan pengaduan yang dapat dilakukan dalam hal Penyedia Barang/Jasa atau masyarakat menemukan indikasi penyimpangan prosedur, KKN dalam pelaksanaan pengadaan barang/jasa Pemerintah dan atau pelanggaran persaingan yang sehat.

Prosedur sanggah berdasarkan Peraturan Presiden tentang Pengadaan Barang/Jasa Pemerintah disampaikan kepada Kelompok Kerja/ULP. Apabila jawaban tersebut menyatakan sanggah yang diajukan tidak benar maka proses pengadaan barang/jasa dilanjutkan, namun apabila dinyatakan sanggah yang diajukan benar maka pengadaan tersebut harus dilakukan evaluasi ulang atau pengadaan barang/jasa ulang. Sehingga membuat hasil yang efektif dan efisien dalam proses pengadaan barang/jasa. 
Sebagai contoh prosedur sanggah apabila suatu instansi melakukan pengadaan barang/jasa Pemerintah berdasarkan Peraturan Presiden, pengadaannya dilakukan secara e-procurement dalam pelaksanaan pengadaan. Setelah dilakukan evaluasi kualifikasi maka ditetapkan pemenang untuk selanjutnya diumumkan pemenangnya. Misalnya pengumuman pemenang dilakukan pada tanggal 7 November 2016, apabila ada peserta pengadaan barang/jasa yang merasa dirugikan karena menemukan penyimpangan terhadap ketentuan dan prosedur yang diatur dalam Peraturan Presiden dan yang telah ditetapkan dalam dokumen pengadaan barang/jasa, adanya rekayasa yang mengakibatkan terjadinya persaingan yang tidak sehat, dan/atau adanya penyalahgunaan wewenang oleh Unit Layanan Pengadaan (ULP) dan/atau pejabat yang berwenang lainnya, maka dapat disampaikan surat sanggahan. Karena pengadaan dilakukan secara e-procurement, surat sanggahan disampaikan kepada ULP dan ditembuskan kepada PPK, PA/KPA dan APIP K/L/D/I yang bersangkutan paling lambat 5 (lima) hari kalender setelah pengumuman pemenang, yaitu diajukan paling lambat pada tanggal 12 November 2016. Dalam contoh di atas masa sanggah dimulai pada tanggal 8 November 2016 sampai dengan tanggal 12 November 2016.

Dengan adanya sanggahan yang disampaikan kepada ULP, selanjutnya ULP wajib memberikan jawaban tertulis atas semua sanggahan paling lambat 5 (lima) hari kalender setelah surat sanggahan diterima. Apabila sanggahan diterima ULP pada tanggal 11 November 2016, maka paling lambat ULP memberikan jawaban pada tanggal 16 November 2016. Apabila jawaban tersebut menyatakan sanggah yang diajukan tidak benar maka proses pengadaan barang/jasa dilanjutkan, namun apabila dinyatakan sanggah yang diajukan benar maka pengadaan tersebut harus dilakukan evaluasi ulang atau pengadaan barang/jasa ulang.

Dalam praktik pelaksanaan pengadaan barang/jasa khususnya dalam lingkup di Kementerian Pekerjaan Umum dan Perumahan Rakyat (Kementerian PUPR), beberapa sanggahan yang dilayangkan kepada panitia bukan terjadi karena salah satu alasan maupun dasar pengajuan sanggah sesuai dalam Peraturan Preseiden. Peserta seringkali melakukan sanggah hanya karena mereka 
merasa tidak puas dan kecewa karena kalah. Sehubungan dengan hal itu maka penyedia memberikan surat sanggah tanpa memberikan bukti serta paparan yang jelas mengenai adanya tindakan penyimpangan prosedur, rekayasa maupun penyalahgunaan wewenang panitia. Selain materi sanggah yang tidak sesuai, dalam beberapa kasus panitia menjumpai penyedia menyampaikan sanggah tidak sesuai dengan ketentuan yang berlaku di dalam Peraturan Presiden tentang Pengadaan Barang/Jasa Pemerintah.

Dalam Peraturan Presiden tentang Pengadaan Barang/Jasa Pemerintah juga diatur mengenai pengaduan yang cakupannya lebih luas yaitu tidak hanya peserta pengadaan saja yang dapat mengajukan pengaduan, namun juga masyarakat yang menemukan indikasi-indikasi penyimpangan tersebut. Pengaduan atas proses pengadaan barang/jasa dapat dilakukan apabila peserta lelang atau masyarakat menemukan indikasi penyimpangan prosedur, KKN dalam pelaksanaan pengadaan barang/jasa dan/atau pelanggaran persaingan yang sehat. Pengaduan tersebut ditujukan kepada Aparatur Pemeriksa Internal Pemerintah instansi (APIP) yang bersangkutan dan/atau Lembaga Kebijakan Pengadaan Pemerintah (LKPP) disertai bukti-bukti kuat yang terkait langsung dengan materi pengaduan. APIP instansi yang bersangkutan dan LKPP menindaklanjuti pengaduan yang dianggap beralasan. Hasil tindak lanjut pengaduan yang dilakukan APIP dilaporkan kepada Pimpinan Institusi dan dapat dilaporkan kepada instansi yang berwenang dengan persetujuan Pimpinan Institusi.

Terhadap proses pengaduan, Kementerian PUPR mempunyai pengaturan mengenai tata cara penanganan masukan dari masyarakat, yaitu dalam Peraturan Menteri PU Nomor 323/PRT/M/2005 tentang Tata Cara Penanganan Masukan Dari Masyarakat di Lingkungan Departemen Pekerjaan Umum masukan dari masyarakat yang mencakup kinerja pelayanan, dugaan adanya tindak pidana umum, dugaan adanya tindak pidana korupsi, kolusi dan nepotisme (KKN), permasalahan yang berpotensi menimbulkan kerawanan sosial dan lingkungan. Penyimpangan yang menimbulkan kerugian negara disampaikan kepada Menteri dan/atau Inspektur Jenderal. Dalam hal ini Inspektorat Jenderal mempunyai tugas 
menyelenggarakan pengawasan interen di lingkungan Kementerian PUPR. Termasuk di dalamnya Inspektorat Jenderal, dalam hal ini sebagai APIP menerima pengaduan pengaduan dalam proses pengadaan barang/jasa.

Penetapan pemenang dan pengumuman pemenang dalam pengadaan barang/jasa pemerintah merupakan Keputusan Pejabat Tata Usaha Negara dalam hal ini Keputusan Kelompok Kerja ULP yang berupa penetapan tertulis yang dikeluarkan oleh pejabat tata usaha negara yang berisi tindakan hukum tata usaha negara yang berdasarkan peraturan penrundang-undangan bersifat konkret, individual, dan final yang menimbulkan akibat hukum bagi orang atau badan hukum perdata. Upaya administrasi terhadap sengketa TUN tentang penetapan pemenang lelang pengadaan barang/jasa Pemerintah, yaitu berupa sanggah. Sanggah merupakan pengajuan surat keberatan yang ditujukan kepada Badan/Pejabat Tata Usaha negara yang mengeluarkan Keputusan (penetapan/beschiking).

Sanggahan diajukan kepada ULP, yaitu unit organisasi yang berfungsi melaksanakan pengadaan barang/jasa yang bersifat permanen, dapat berdiri sendiri atau melekat pada unit yang sudah ada. Pemilihan penyedia barang/jasa dalam ULP dilakukan oleh Kelompok Kerja, selanjutnya proses tahapan pemilihan penyedia barang dilakukan oleh Kelompok Kerja. Upaya administrasi tentang penetapan pemenang lelang pengadaan barang/jasa pemerintah, yaitu berupa sanggah ditujukan kepada Badan/Pejabat Tata Usaha negara yang mengeluarkan Keputusan (penetapan/beschiking).

Selain itu juga di Indonesia ada Komisi Pengawas Persaingan Usaha (KPPU) yang dibentuk berdasarkan Undang-Undang Nomor 5 Tahun 1999 tentang Larangan Praktek Monopoli dan Persaingan Usaha Tidak Sehat untuk mengawasi dan melakukan penindakan terhadap praktek monopoli dan atau persaingan usaha tidak sehat. KPPU mempunyai kewenangan untuk menerima, melakukan penelitian, melakukan penyelidikan atau pemeriksaan, memutuskan dan menetapkan ada atau tidaknya dugaan praktek monopoli dan atau persaingan usaha tidak sehat. 
KPPU mempunyai tugas sebagai berikut:

1. melakukan penilaian terhadap perjanjian yang dapat mengakibatkan terjadinya praktek monopoli dan atau persaingan usaha tidak sehat;

2. melakukan penilaian terhadap kegiatan usaha dan atau tindakan pelaku usaha yang dapat mengakibatkan terjadinya praktek monopoli dan atau persaingan usaha tidak sehat;

3. melakukan penilaian terhadap ada atau tidaknya penyalahgunaan posisi dominan yang dapat mengakibatkan terjadinya praktek monopoli dan atau persaingan usaha tidak sehat;

4. mengambil tindakan sesuai dengan wewenang Komisi;

5. memberikan saran dan pertimbangan terhadap kebijakan Pemerintah yang berkaitan dengan praktek monopoli dan atau persaingan usaha tidak sehat;

6. menyusun pedoman dan atau publikasi yang berkaitan dengan UndangUndang ini; dan

7. memberikan laporan secara berkala atas hasil kerja Komisi kepada Presiden dan Dewan Perwakilan Rakyat.

Sedangkan wewenang KPPU adalah:

1. menerima laporan dari masyarakat dan atau dari pelaku usaha tentang dugaan terjadinya praktek monopoli dan atau persaingan usaha tidak sehat;

2. melakukan penelitian tentang dugaan adanya kegiatan usaha dan atau tindakan pelaku usaha yang dapat mengakibatkan terjadinya praktek monopoli dan atau persaingan usaha tidak sehat;

3. melakukan penyelidikan dan atau pemeriksaan terhadap kasus dugaan praktek monopoli dan atau persaingan usaha tidak sehat yang dilaporkan oleh masyarakat atau oleh pelaku usaha atau menghadirkan pelaku usaha, saksi, saksi ahli, atau setiap orang sebagaimana dimaksud huruf e dan huruf f, yang tidak bersedia memenuhi panggilan Komisi;

4. meminta keterangan dari instansi Pemerintah dalam kaitannya dengan penyelidikan dan atau pemeriksaan terhadap pelaku usaha yang melanggar ketentuan Undang-Undang ini; 
5. mendapatkan, meneliti, dan atau menilai surat, dokumen, atau alat bukti lain guna penyelidikan dan atau pemeriksaan;

6. memutuskan dan menetapkan ada atau tidak adanya kerugian di pihak pelaku usaha lain atau masyarakat;

7. memberitahukan putusan Komisi kepada pelaku usaha yang diduga melakukan praktek monopoli dan atau persaingan usaha tidak sehat; dan

8. menjatuhkan sanksi berupa tindakan administratif kepada pelaku usaha yang melanggar ketentuan Undang-Undang ini.

Dari segi penegakan hukum KPPU memiliki tugas dan wewenang untuk melakukan penyidikan, penuntutan dan juga sekaligus sebagai pengadilan sebagaimana diatur UU Nomor 5 tahun 1999. Dalam menjalankan tugasnya KPPU melakukan pemeriksaan terhadap dugaan pelanggaran persaingan usaha atas inisiatif sendiri. Namun KPPU juga memberikan kesempatan pada masyarakat dan atau pelaku usaha lain untuk melaporkan dugaan terjadinya praktek monopoli dan persaingan usaha tidak sehat, untuk ditindaklanjuti. KPPU dapat memberikan putusan dan menjatuhkan sanksi kepada pelaku usaha yang terbukti melakukan praktek yang menghambat persaingan usaha tersebut. Dengan demikian KPPU dalam melakukan pemeriksaan perkara persaingan usaha melalui 3 (tiga) cara, yaitu inisiatif KPPU sendiri, laporan dari pelaku usaha yang dirugikan dan laporan dari masyarakat.

Bahwa dalam proses pemeriksaan dalam penanganan perkara di KPPU menilai alat-alat bukti keterangan saksi, keterangan ahli, surat atau dokumen, petunjuk dan keterangan pelaku usaha. Yang selanjutnya Putusan Komisi harus dibacakan dalam sidang yang dinyatakan terbuka untuk umum dan segera diberitahukan kepada pelaku usaha. Selain itu, KPPU juga mempunyai jangka waktu dalam melakukan pemeriksaan setelah adanya laporan. Namun dalam praktiknya KPPU melebihi jangka waktu yang telah diatur sehingga dapat menimbulkan ketidakpastian hukum karena jangka waktu yang tidak tepat.

Tahapan-tahapan yang panjang dalam prosesnya juga menciptakan ketidakpastian dalam proses pengadaan barang jasa apabila permasalahan upaya keberatan dilakukan oleh KPPU. Proses panjang tersebut adalah tahap 
pengumpulan indikasi, tahap pemeriksaan pendahuluan, tahap pemeriksaan lanjutan, tahap penjatuhan putusan, dan tahap eksekusi putusan.

Terhadap putusan KPPU pelaku usaha dapat mengajukan keberatan melalui Pengadilan Negeri dalam lingkup peradilan umum. Badan peradilan di Indonesia berdasarkan Undang-Undang Dasar 1945 mengenai Kekuasaan Kehakiman merupakan kekuasaan yang merdeka untuk menyelenggarakan peradilan guna menegakkan hukum dan keadilan. Kekuasaaan kehakiman dilakukan oleh Mahkamah Agung dan badan peradilan yang salah satu berada di bawahnya adalah lingkungan peradilan umum. Prinsip-prinsip peradilan di Indonesia antara lain peradilan yang bebas tidak memihak, peradilan yang transparan dan kontrol sosial, persamaan kedudukan orang di depan hukum yang untuk membantu pencari keadilan dan berusaha mengatasi segala hambatan dan rintangan untuk dapat tercapainya peradilan yang sederhana, cepat dan biaya ringan.

Namun dalam praktik peradilan umum, tujuan tercapainya peradilan yang sederhana, cepat dan biaya ringan tidak dapat terpenuhi dengan baik. Dengan adanya proses yang panjang dan sangat lama apabila dikaitkan dengan permasalahan persaingan usaha dapat menimbulkan iklim usaha yang tidak baik. Hingga saat ini prosedur tersebut dijalankan dalam rangka menerapkan persaingan usaha yang sehat.

\section{Penutup}

Dikaitkan dengan prosedur Challenge dalam GPA yang ketentuannya dapat berupa pengadilan atau suatu badan imparsial dan independen yang tidak mempunyai kepentingan dalam pengadaan barang/jasa yang aman dari pengaruh eksternal, maka prosedur sanggah dalam proses pengadaan barang/jasa pemerintah dan prosedur penyelesaian sengketa di KPPU belum sesuai dengan ketentuan dalam GPA karena sanggah diajukan kepada ULP yang tidak mempunyai prosedur sebagai berikut: peserta dapat didengarkan pendapatnya terlebih dahulu sebelum keputusan diambil, adanya keadaan peserta dapat diwakili dan ikut, peserta memiliki akses ke dalam proses, proses berlangsung 
terbuka secara umum, pendapat atau keputusan diberikan secara tertulis dengan menjelaskan pertimbangan-pertimbangan terhadap putusan yang diambil, adanya kesempatan saksi untuk dihadirkan, dan dokumen yang tidak tertutup terhadap badan peninjau tersebut.

Sedangkan proses pemeriksaan di KPPU walaupun terdapat pengaturan tentang prosedur peserta dapat didengarkan pendapatnya terlebih dahulu sebelum keputusan diambil, adanya keadaan peserta dapat diwakili dan ikut, peserta memiliki akses ke dalam proses, proses berlangsung terbuka secara umum, pendapat atau keputusan diberikan secara tertulis dengan menjelaskan pertimbangan-pertimbangan terhadap putusan yang diambil, adanya kesempatan saksi untuk dihadirkan, dan dokumen yang tidak tertutup terhadap badan peninjau tersebut, namun berbeda dengan prosedur Challenge yang diatur dalam GPA.

Dengan adanya upaya untuk memenuhi persaingan yang sehat dalam proses pelaksanaan pengadaan barang/jasa di Indonesia, yaitu adanya prosedur sanggah, pengaduan maupun proses pemeriksaan oleh KPPU masih ditemui adanya kelebihan dan kekurangan di masing-masing prosedur. Apabila proses sanggah tersebut dinyatakan tidak benar maka proses pengadaan barang/jasa dilanjutkan, namun apabila sanggah yang diajukan dinyatakan benar maka pengadaan tersebut harus dilakukan evaluasi ulang atau pengadaan barang/jasa ulang. Proses tersebut dilaksanakan dengan adanya jangka waktu yang mengatur sehingga cepat mendapat keputusan dan menimbulkan kepastian hukum di dalamnya. Namun adanya proses yang panjang dan sangat lama dalam pemeriksaan di KPPU yang putusannya dapat diajukan keberatan ke peradilan umum, dapat menimbulkan iklim usaha yang tidak baik karena tidak adanya kepastian hukum terhadap keputusan KPPU yang bersifat eksekutorial.

Penyesuaian prosedur Challenge dalam GPA melalui pelaksanaan pengadaan barang/jasa di Indonesia diterapkan dalam rangka perdagangan internasional untuk menuju program-program yang telah disepakati di WTO. Ke depan cepat atau lambat Indonesia memasuki perdagangan internasional yang 
sangat bebas, sehingga diperlukan kesiapan infrastruktur Indonesia untuk perdagangan bebas.

Panitia pelelangan atau kelompok kerja dalam ULP tidak bisa menghindari sanggah. Walaupun panitia sudah bekerja sebaik dan seteliti mungkin, belum tentu semua calon penyedia bisa menerima keputusan panitia. Sanggah adalah hak penyedia lelang untuk menyampaikan keberatan atas hasil lelang. Selain itu sanggah adalah alat kontrol bagi panitia agar bekerja sesuai dengan ketentuan yang berlaku. Jadi, sangat penting bagi panitia memahami aturan Peraturan Presiden tentang Pengadaan Barang/Jasa Pemerintah yang termasuk di dalamnya mengatur mengenai sanggah. Sanggah bukan merupakan tolok ukur kinerja panitia, tetapi sanggah adalah mekanisme kontrol agar panitia siap menghadapi segala kemungkinan. Walaupun sanggah bukan tolok ukur kinerja panitia, tetapi kemampuan panitia akan diuji ketika dia berhasil menghadapi sanggah dengan baik. Seorang panitia yang sangat memahami prosedur tentu akan lebih percaya diri ketika memutuskan hasil lelang. Jika panitia yakin bahwa keputusan yang diambil sudah sesuai, tidak ada penyelewengan, rekayasa maupun penyalahgunaan wewenang, maka bisa dipastikan panitia juga akan siap menghadapi kemungkinan terjadinya sanggah. Sebagai penutup, dapat penulis sampaikan bahwa jika seorang panitia merasa yakin bahwa setiap keputusan yang diambil itu sudah benar dan sesuai aturan, maka dia tidak perlu takut untuk menghadapi sanggah.

Indonesia dalam melakukan liberalisasi di bidang pengadaan barang/jasa Pemerintah harus membuka transparansi terlebih dahulu, dan pengadaan barang/jasa dilakukan secara efektif dan efisien serta adanya persaingan yang adil. Selain itu praktik korupsi, kolusi dan nepotisme dalam pengadaan barang/jasa pemerintah yang ada harus terus diminimalisir dan dihapuskan.

\section{Daftar Pustaka}

\section{Buku}

Agus Yudha Hernoko, Hukum Perjanjian Asas Proporsionalitas Dalam Kontrak Komersial, Kencana Prenadamedia Group, Jakarta, 2004. 
Kartajoemena H.S., GATT, WTO dan Hasil Uruguay Round, Universitas Indonesia, Jakarta, 2002.

Mochammad Jasin, Mencegah Korupsi Melalui E-procurement, Komisi Pemberantasan Korupsi, Jakarta, 2007.

Samsul Ramli, Bacaan Wajib Para Praktisi Pengadaan Barang/Jasa Pemerintah, Visimedia, Jakarta, 2013.

Soerjono Soekanto dan Sri Mamudji. Penelitian Hukum Normatif: Suatu Tinjauan Singkat, Rajawali Pers, Jakarta, 2012.

\section{Sumber Hukum}

Herzein Inlandsch Reglement (HIR).

Kitab Undang-Undang Hukum Acara Pidana (KUHAP).

Undang-Undang Nomor 5 Tahun 1999 tentan Larangan Praktek Monopoli Dan Persaingan Usaha Tidak Sehat.

Peraturan Presiden Republik Indonesia Nomor 54 Tahun 2010 tentang Pengadaan Barang/Jasa Pemerintah.

Peraturan Presiden Republik Indonesia Nomor 35 Tahun 2011 tentang Perubahan Atas Peraturan Presiden Republik Indonesia Nomor 54 Tahun 2010 tentang Pengadaan Barang/Jasa Pemerintah.

Peraturan Presiden Republik Indonesia Nomor 70 Tahun 2012 tentang Perubahan Kedua Atas Peraturan Presiden Republik Indonesia Nomor 54 Tahun 2010 tentang Pengadaan Barang/Jasa Pemerintah.

Peraturan Presiden Nomor 172 Republik Indonesia Tahun 2014 tentang Perubahan Ketiga Atas Peraturan Presiden Republik Indonesia Nomor 54 Tahun 2010 tentang Pengadaan Barang/Jasa Pemerintah.

Peraturan Presiden Republik Indonesia Nomor 4 Tahun 2015 tentang Perubahan Keempat Atas Peraturan Presiden Republik Indonesia Nomor 54 Tahun 2010 tentang Pengadaan Barang/Jasa Pemerintah.

Peraturan Menteri PU Nomor 323/PRT/M/2005 tentang Tata Cara Penanganan Masukan Dari Masyarakat di Lingkungan Departemen Pekerjaan Umum.

The General Agreement On Tariffs And Trade, Geneva, July 1986, Agreement On Government Procurement.

\section{Lainnya}

Agreement on Government Procurement Parties, Observers and Accessions diakses dari https://www.wto.org/english/tratop_e/gproc_e/memobs_e.html

Kwik Kian Gie, Kebijakan Pengadaan Barang/Jasa Instansi Pemerintah (Government's Goods/Services Procurement), Naskah pidato Menteri Negara Perencanaan Pembangunan Nasional/Kepala Bappenas pada Pertemuan Tingkat Menteri di Jakarta, dalam Konferensi Tingkat Menteri (KTM) WTOV di Cancun Mexico, 7 Agustus 2003

Understanding The WTO Settling Disputes diakses dari

https://www.wto.org/english/thewto_e/whatis_e/tif_e/disp1_e.htm 